INTERLEUKIN-1 (IL-1) is an inflam matory mediator that increases $\mathrm{Cl}^{-}$secretion in in testin al epith elial cells. To identify the signal transduction pathway(s) involved in IL-1's action, cells were treated with IL-1 and the levels of cyclooxygenase (COX) enzymes, prostaglandin $E_{2}\left(P_{2} E_{2}\right)$ and phospholipase $A_{2}$-activating protein (PLAP), and the activity of phospholipase $A_{2}$ $\left(P_{2}\right)$ were measured. IL-1 caused concentrationand time-dependent increases in the levels of $\mathrm{PLA}_{2}$ activity, and/or in the levels of PLAP, COX-2 and PGE 2 . The IL-induced increase in $\mathrm{PGE}_{2}$ levels was biphasic, with the first peak due to the increase in PLAP levels, and the second peak due to the increase in COX-2 levels. This increase in $\mathrm{PGE}_{2}$ levels may provide a mechanism for acute and chronic inflammation in the in testine.

Key words: Interleukin-1 receptor, Cytokines, Prostaglandin $\mathrm{E}_{2}$ production, Epithelial cells, Inflammatory bowel disease

\section{The mechanisms of action of interleukin-1 on rabbit intestinal epithelial cells}

\author{
Fadia R. Homaidan ${ }^{1, C A}$, Liming Zhao ${ }^{2}$, \\ Iman Chakroun ${ }^{1}$, Carla A. Martin ${ }^{2}$ and \\ Robert Burakoff ${ }^{2,3}$
}

${ }^{1}$ Department of Physiology, Faculty of Medicine, American University of Beirut, Beirut, Lebanon; ${ }^{2}$ Division of Gastroenterology, Winthrop-University Hospital, Mineola, NY; and ${ }^{3}$ Stony Brook School of Medicine, Stony Brook, NY, USA

\author{
${ }^{\mathrm{CA}}$ Corresponding Author \\ Address: American University of Beirut, Department of \\ Physiology, Faculty of Medicine, Beirut, Lebanon \\ Tel: (+1) 9613222530 \\ Fax: (+1) 9611744464 \\ Email: fh01@aub.edu.1b
}

\section{Introduction}

Many cell functions are regulated by members of the cytokine receptor superfamily. Signaling by these receptors depends upon their association with different second messengers and signal transduction systems. Interleukin-1 (IL-1), which is produced by macrophages/monocytes, plays a central role in immune and inflammatory responses, acts on a varie ty of cell types, and exhibits multiple biological activities. IL-1 signal follows binding to specific receptors on the cell surface. Studies have revealed the presence of two types of IL-1 receptors: T-cell/ fibroblast type I receptor expressed on $\mathrm{T}$ cells, epithelial cells and fibroblasts; and type II receptor expressed on B cells, macrophages and myeloid cells. ${ }^{1-3}$ Murine and human cDNA for both receptors have been cloned and their amino acid sequences have been reported. ${ }^{2,3}$ The two IL-1 receptors are transmembrane glycoproteins of the immunoglobulin (Ig) superfamily organized into three IgG-like ex tracellular domains and share $28 \%$ amino acid sequence identity. ${ }^{2}$

In the intestine, IL-1 has been shown to be an important inflammatory mediator whose levels are increased in inflammatory bowel disease. ${ }^{4,5}$ Recently, we reported that IL-1 stimulates the synthesis of prostaglandin $\mathrm{E}_{2} \quad\left(\mathrm{PGE}_{2}\right)$ in rabbit distal colon, ${ }^{6}$ partially through the induction of synthesis of a phospholipase- $\mathrm{A}_{2}$ activating protein (PLAP). PLAP in turn activates $\mathrm{PLA}_{2}$, which causes an increase in prostanoid synthesis. ${ }^{7,8}$ The aim of this study was to investigate whether IL-1 exerts its effects directly on epithelial cells through binding to specific IL-1 receptor binding sites on epithelial cell membranes, and to identify the signal transduction system(s) involved in the mechanism of action of acute and chronic exposure of IL-1 on epithelial cell function.

\section{Materials and methods}

\section{Materials}

Human recombinant IL-1 $\beta$ w as obtaine $d$ as a gift from Dr P. Smith and Dr J. Lee at Smith Kline and Beecham (Philadelphia, PA). Acrylamide, $N^{\prime}, N^{\prime}$-bis-methyle neacrylamide, sodium dodecyl sulfate (SDS), glycine, bromophenol blue, coomassie blue R-250, alkaline phosphatase conjugated goat anti-rabbit IgG, ImmunLite II chemiluminescent protein detection system and PVDF membrane were from Bio-Rad Laboratory (Melville, NY). Hydrocortisone, insulin, transferrin 
and selenium were from ITS Collaborative Research (Bedford, MA). Fluorescein isothiocyanate (FITC) conjugated goat anti-rabbit $\operatorname{IgG}$ was from Jackson ImmunoResearch Labs (West Grove, PA). Penicillin and streptomycin, RPMI, Dulbecco's Modified Eagle's Medium (DMEM), goat serum and Earl's balanced salt solution were from Gibco Laboratories (Grand Island, $\mathrm{NY}$ ). All the other chemicals were from Sigma (St. Louis, MO).

\section{Methods}

\section{(1) Primary culture of rabbit colonic epithelial} cells:

Colonocytes were prepared as described recently. ${ }^{9}$ The distal colon was removed and washed in phosphate buffered saline (PBS) containing penicillin $(100 \mathrm{U} / \mathrm{ml})$, streptomycin $(100 \mu \mathrm{g} / \mathrm{ml})$, fungizone $(10 \mu \mathrm{g} / \mathrm{ml})$ and gentamycin $(100 \mu \mathrm{g} / \mathrm{ml})$. Colonocytes were dissociated by exposing the washed tissue to dispase (neutral protease $\mathrm{mix}, 3 \mathrm{mg} / \mathrm{ml}$ ) prepared in DMEM, low glucose containing $10 \%$ fetal calf serum, $100 \mathrm{U} / \mathrm{ml}$ penicillin and $100 \mu \mathrm{g} / \mathrm{ml}$ streptomycin, and $50 \mu \mathrm{g} / \mathrm{ml}$ gentamycin and $5 \mu \mathrm{g} / \mathrm{ml}$ fungizone) for $1 \mathrm{~h}$ at $37^{\circ} \mathrm{C}$. The mucosal surface was scraped after digestion to release cells, which were then recovered by centrifugation at $800 \mathrm{xg}$ for $5 \mathrm{~min}$. Cells were then placed onto plates containing mitomycin growtharrested feeder cells (Sw iss 3T3 fibroblasts, ATCC no. CCL 92) in DMEM supplemented by $20 \%$ fetal calf serum, hydrocortisone $(0.5 \mu \mathrm{g} / \mathrm{ml})$, and a mixture of insulin $(5 \mu \mathrm{g} / \mathrm{ml})$, transferrin $(5 \mu \mathrm{g} / \mathrm{ml})$ and selenium $(5 \mathrm{ng} / \mathrm{ml})$ with penicillin $(100 \mathrm{U} / \mathrm{ml})$, streptomycin $(100 \mu \mathrm{g} / \mathrm{ml})$ and gentamycin $(40 \mu \mathrm{g} / \mathrm{ml})$. Cultures were selected by differential plating for the epithelial population at the first two serial passages, making use of the fact that fibroblasts attach to cell culture plates very fast while the epithelial cells do not. Epithelial cells were used only between the third and sixth passages. At the passages used, these cells were positive for cytokeratin staining (epithelial cell-specific marker) and negative for vimentin staining (fibroblast cell marker) as has been shown previously. ${ }^{9}$ Cells from different animals were used to increase the number, $n$.

To prepare cell homogenates, cells were scraped off the culture flasks in homogenization buffer consisting of: $62.5 \mathrm{mM}$ Tris- $\mathrm{HCl}, 2 \mathrm{mM} \mathrm{Na}{ }_{2}$-EDTA, $1 \mathrm{mM}$ PMSF, $1 \mathrm{mM}$ benzamidine, $\mathrm{pH} 6.8$, containing $10 \mu \mathrm{g} / \mathrm{ml}$ each of aprotinin, soybean trypsin inhibitor, leupeptin and antipain. Cells were homogenized in $2 \mathrm{ml}$ homogenization buffer by a Dounce homogenizer for 10 strokes and then sonicated (model XL2005 sonicator, Heat Systems Inc., Farmingdale, $\mathrm{NY}$ ) for $10 \mathrm{~s}$. The homogenate $\mathrm{w}$ as then centrifuge $\mathrm{d}$ at $500 \mathrm{xg}$ for $10 \mathrm{~min}$ to remove cell debris, and the resulting supernatant was used for samples to run on the polyacrylamide gels.
(2) Polyacrylamide gel electrophoresis and Western blot analysis:

Polyacrylamide gel electrophoresis was performed according to Laemmli ${ }^{10}$ in a module Mini-Protein II electrophoresis system (Bio-Rad laboratories). Samples $(10 \mu \mathrm{g}$ each) were loaded on $12 \%$ SDS-polyacrylamide gel. Proteins were separated (using constant voltage of $200 \mathrm{~V}$ ) for $45 \mathrm{~min}$ and then transferred to a PVDF membrane using the mini Trans-Blot electrophoretic transfer cell (Bio-Rad Laboratories, $100 \mathrm{~V}$ and $250 \mathrm{~mA}$ for $1 \mathrm{~h}$ ). Following transfer, the membrane was washed in Tris-buffer saline (TBS), then incubated with $5 \%$ non-fat dry milk in TBS for $1 \mathrm{~h}$ at room temperature followed by another washing with TBS containing $0.5 \%$ Tween- 20 (TTBS). The membrane was incubated with the first antibody (anti-IL-1 receptor antibodies: sheep antihuman IL-1R type I-R3 was a generous gift from Dr J. E. Sims, Immunex Corporation, Seattle, WA; or antimelittin antibodies for the detection of PLAP which were a generous gift from Dr J. Bomalaski, Medical College of Pennsylvania, PA; or with cyclooxygenase (COX)-polyclonal anti PGHS purchased from Accurate, Westbury, NY) at 1:500 dilution in $1 \%$ non-fat dry milk in TBS for $16 \mathrm{~h}$. The membrane was washed with TTBS, then incubated with alkaline phosphatase conjugated goat-anti-rabbit $\mathrm{IgG}$ for $2 \mathrm{~h}$. The membrane was washed with TTBS again, and incubated with the enhancer (Immun-lite, Bio Rad Laboratories) for $30 \mathrm{~min}$. The Immun-Lite II chemiluminescent detection system was used to detect the immunoreaction bands on the membrane. A PhosphorImager SF Scanning system and ImageQuant software (Molecular Dynamics, Sunnyvale, CA) were used for the scanning and estimation of each band density.

\section{(3) Flow cytometry:}

Samples containing at least $1 \times 10^{6}$ cells were incubated on ice for $60 \mathrm{~min}$ with $50 \mu \mathrm{l}$ rabbit gamma globulin (Sigma, St. Louis, MO) at $10 \mathrm{mg} / \mathrm{ml}$ to block Fc receptor binding, and $100 \mu 1$ of a $1 / 100$ dilution of either normal sheep serum (Jackson Immunoresearch laboratories Inc., Westgrove, PA) or sheep anti-human IL-1 receptor type I serum (Immunex). Samples were washed tw ice with PBS containing $0.1 \%$ bovine serum albumen and $0.1 \% \mathrm{NaN}_{3}$ (PBSA), and then incubated on ice for $30 \mathrm{~min}$ with a $1 / 50$ dilution of FITCconjugated donkey anti-sheep IgG (heavy and light chains) (Jackson Immunoresearch Labs Inc.) that had been absorbed to remove activity to rabbit serum proteins. The samples were washed three times in PBS and resuspended in PBS containing 2\% paraformaldehyde for analysis on a Becton Dickinson FACSCAN using the Consort 30 software. Live gates were set based on forward scatter profiles. The KolmogorovSmirnov Test was used to determine the significance of a shift in fluorescent intensity of IEC stained with 
antibody to IL-1 receptors. ${ }^{11}$ Discrimination of dead and live cells was performed by the two-color analysis using FITC and propidium iodide (PI). Dead cells were gated out with PI.

(4) Measurement of total PLA $A_{2}$, secretory $P L A_{2}$ and cytoplasmic PLA $A_{2}$ activities:

Purified porcine pancreatic PLA 2 (ICN Biochemicals, Cleveland, $\mathrm{OH}$ ) was used as a standard. The supernatant was removed from the cells and homogenization buffer (containing $62.5 \mathrm{mM}$ Tris- $\mathrm{HCl}, 10 \mu \mathrm{g} / \mathrm{ml}$ aprotinin, $10 \mu \mathrm{g} / \mathrm{ml}$ soybean trypsin inhibitor, $10 \mu \mathrm{g} / \mathrm{ml}$ leupeptin, $10 \mu \mathrm{g} / \mathrm{ml}$ pepstatin $\mathrm{A}, 12 \mathrm{mM}$ benzamidine, $1 \mathrm{mM}$ PMSF and $10 \mu \mathrm{g} / \mathrm{ml}$ antipain) was added. The cells were homogenized using Dounce homogenizer for 10 strokes then sonicated for $10 \mathrm{~s}$. Assays for measuring $\mathrm{PLA}_{2}$ activity were done using the $\mathrm{PLA}_{2}$ assay kits from Cayman Chemical (Ann Arbor, MI). The assay uses the thio ester derivative of the appropriate substrate for the specific $\mathrm{PLA}_{2}$ type to be measured. Upon hydrolysis of the thio ester bond at the sn-2 position by $\mathrm{PLA}_{2}$, free thiols are detected using 5,5'-dithiobis (2-nitrobenzoic acid).

\section{(5) Measurement of $P G E_{2}$ levels:}

Cells were incubated w ith IL-1 $\beta(10 \mathrm{ng} / \mathrm{ml})$ for $30 \mathrm{~min}$ in culture medium. Aliquots from the supernatant were transferred to Eppendorf tubes and centrifuged at $4^{\circ} \mathrm{C}$, for $2 \mathrm{~min}$ at $9000 \mathrm{rpm}$ in the Eppendorf centrifuge. Samples were kept at $-70^{\circ} \mathrm{C}$ for later determination of $\mathrm{PGE}_{2}$ levels using radio immunoassay (RIA). Commercially available RIA kits for measurement of $\mathrm{PGE}_{2}$ were used (Advanced Magnetics Inc., MA). The assay involved incubating the sample with the corresponding antiserum overnight at $4^{\circ} \mathrm{C}$ and then centrifuging for $15 \mathrm{~min}$ at $4^{\circ} \mathrm{C}$ at $1000 \mathrm{xg}$. The supernatant $\mathrm{w}$ as then transferred to scintillation vials, and scintillant added and vial counted in a liquid scintillatio $n$ counter.

\section{Results}

\section{Identification of the IL-1 receptor protein on epithelial cells}

For the epithelial cells to be directly regulated by IL-1, the receptor for IL-1 has to be present on the cell membranes. Using Western blot analysis, we were able to show that IL-1 receptor is indeed present in normal unstimulated epithelial cells (Fig. 1). The receptor identified had an apparent molecular weight at $80 \mathrm{kD}$, consistent $w$ ith the IL-1R type I. Using similar methodology, IL-1 R type II (Sheep anti-human IL-1R type II was a generous gift from Immunex) was not present on these epithelial cells (data not shown).

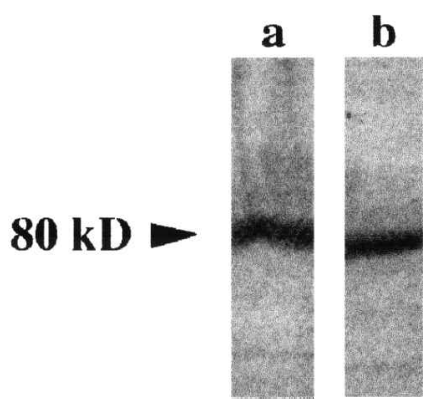

FIG. 1. A representative Western blot (one of three experiments) showing the presence of the IL-1 receptor type I (size, $80 \mathrm{kD}$ ) in the cultured colonic epithelial cells (lane a). Lane b shows the presence of the IL-1 receptor in human monocytes as a positive control.

Flow cytometry experiments were also performed to further prove the presence of the receptor on the isolated epithelial cells. Forward scatter of epithelial cells revealed the presence of one population of cells based on size. Cells were treated with either immune serum (antibodies obtained as a gift from Immunex as listed in Materials) or nonimmune serum (controls). They showed a shift in fluorescence (Fig. 2) which was significant (total number of experiments $=4 ; P<0.001$ ), indicating the presence of the receptor on the epithelial cells. Similar experiments were repeated using antibodies to IL-1R type II (Sheep anti-human IL-1R type II was a generous gift from Immunex). No IL-1R type II was present on the epithelial cells (data not shown).

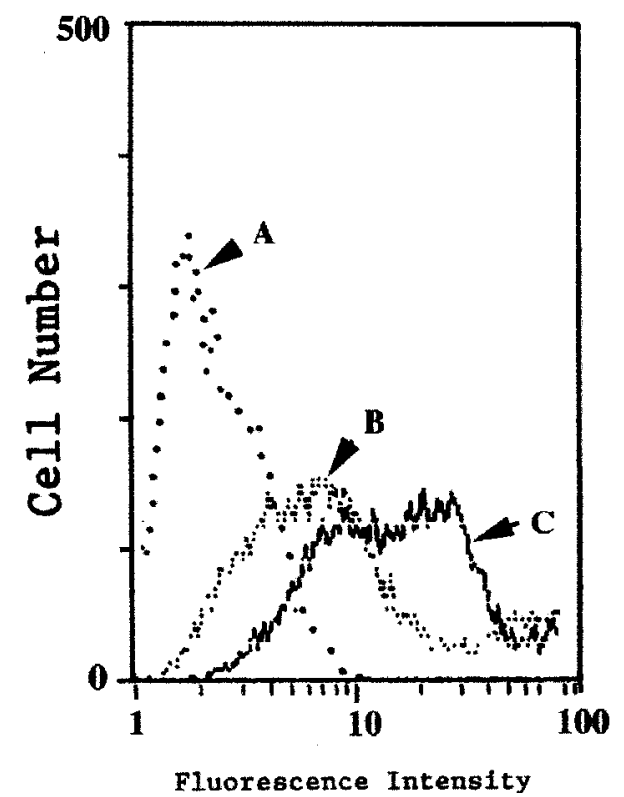

FIG. 2. Single-parameter fluorescence histograms (one of three experiments) of: (A) unstained cells, (B) cells stained with non-immune serum, and (C) cells stained with antibodies against IL-1R type I. There was a significant shift in fluorescence $(P<0.001)$, indicating the presence of the receptor on the epithelial cells. 


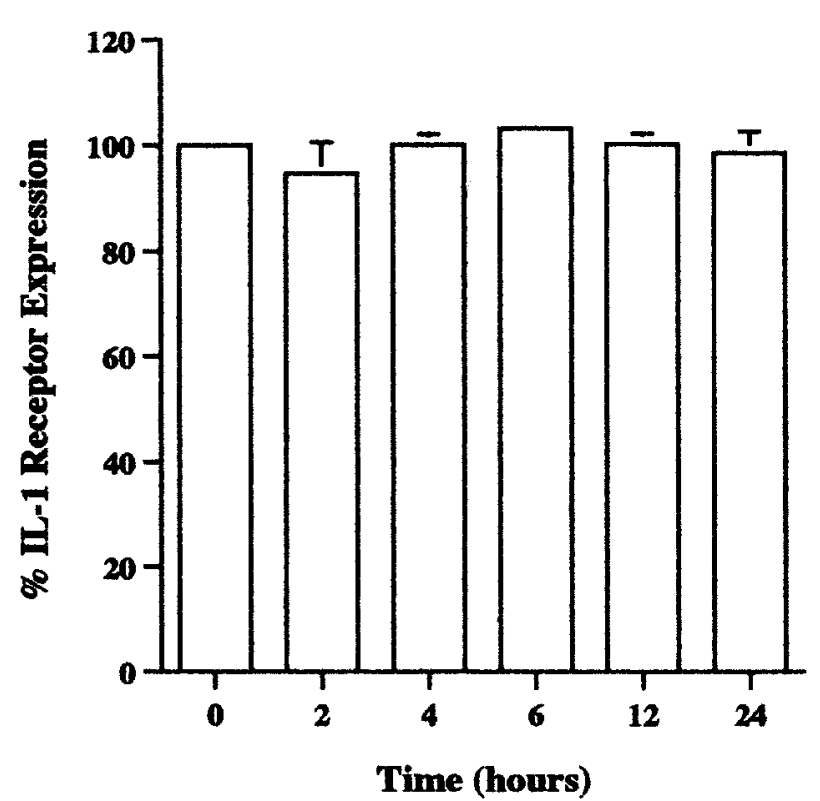

FIG. 3. Levels of IL-1 receptor, type I, in rabbit colonocytes treated with IL-1 $(30 \mathrm{ng} / \mathrm{ml})$ for different time periods. No significant increase in the receptor levels was observed at any of the times tested. Data are means \pm SE for four separate experiments.
Using Western blotting assays, we tested whether long exposure of IL-1 regulates the levels of IL-1R. The levels of IL-1 receptor were not changed by treatment by IL-1 for up to $24 \mathrm{~h}$ (Fig. 3).

\section{PLAP levels in epithelial cells}

Intestinal epithelial cells were incubated with IL-1 $\beta$ at different concentrations and for different time periods, and the levels of PLAP measured using Western blotting assays. PLAP levels were significantly increased when cells were treated $w$ ith IL-1 $\beta$ to reach maximal levels between 10 and $30 \mathrm{~min}$ with IL- $\beta$ concentration of $30 \mathrm{ng} / \mathrm{ml}$ (Fig. 4). PLAP levels went back to baseline levels afterwards and stayed there even $24 \mathrm{~h}$ post-treatment with IL-1 $\beta$.

\section{Activity of PLA 2 in epithelial cells}

Epithelial cells were incubated with different concentrations of IL-1 $\beta$ for diffe rent lengths of time, and the activity of secretory $\left(\mathrm{SPLA}_{2}\right)$, cytoplasmic $\mathrm{PLA}_{2}$ $\left(c P L A_{2}\right)$ and total $\mathrm{PLA}_{2}$ enzymes measured. sPLA
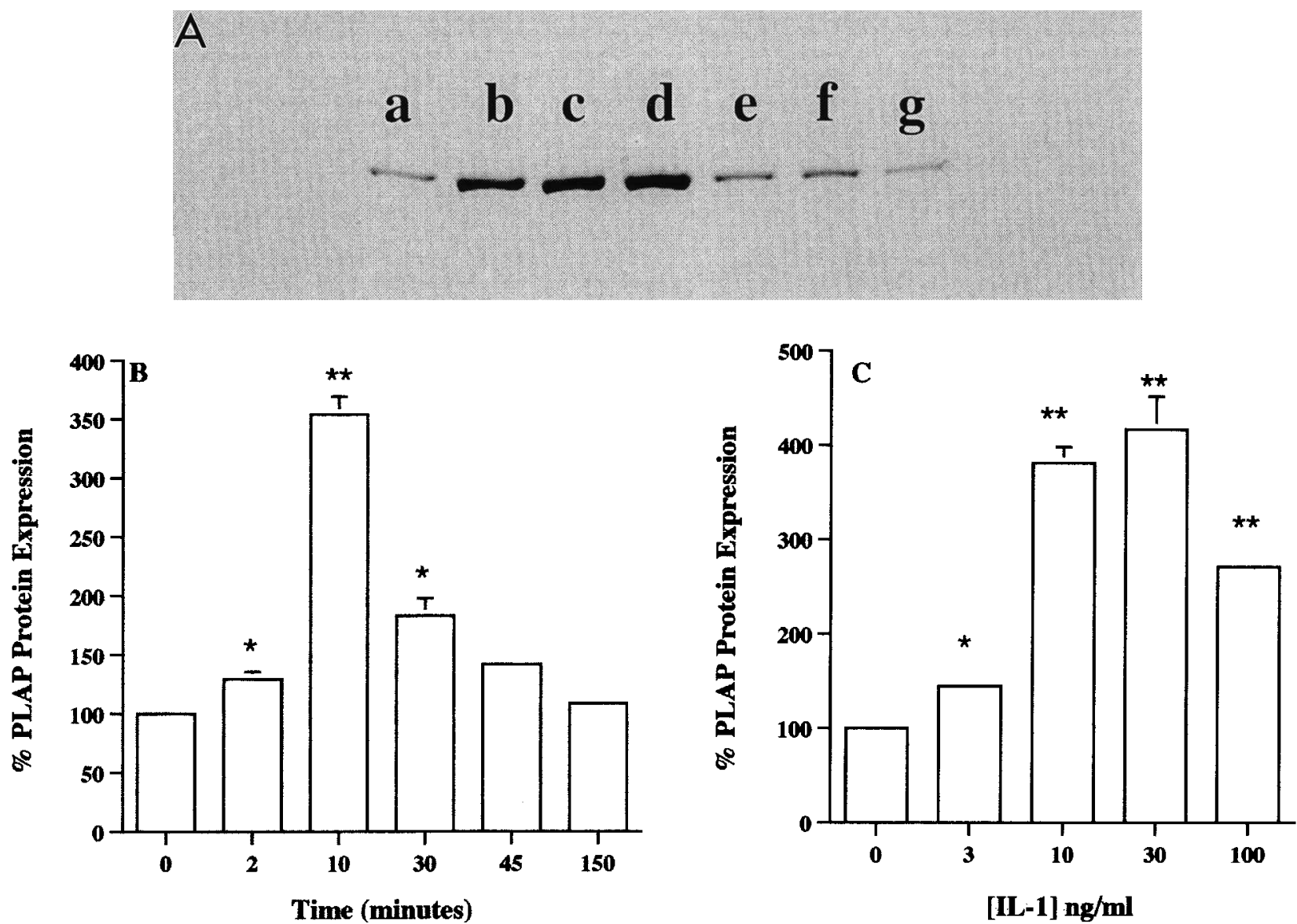

FIG. 4. (A) A representative Western blot (one of four experiments) showing the presence of PLAP (size, $42 \mathrm{kD}$ ) and its induction in cells treated with IL-1 $(10 \mathrm{ng} / \mathrm{ml})$ for different time periods. Lane a, $0 \mathrm{~min}$; lane b, $2 \mathrm{~min}$; lane c, $10 \mathrm{~min}$; lane d, $30 \mathrm{~min}$; lane e, $1 \mathrm{~h}$; lane $\mathrm{f}, 12 \mathrm{~h}$; and lane $\mathrm{g}, 24 \mathrm{~h}$. (B) Levels of PLAP in cells treated with IL-1 $(10 \mathrm{ng} / \mathrm{ml})$ for different time periods. (C) Levels of PLAP in cells treated with different concentrations of IL-1 for $10 \mathrm{~min}$. ${ }^{*} P<0.05,{ }^{*} P<0.005 ; P$ value represents the comparison of the effect of IL-1 on PLAP levels as compared with untreated control. Data are means \pm SE for four separate experiments. 

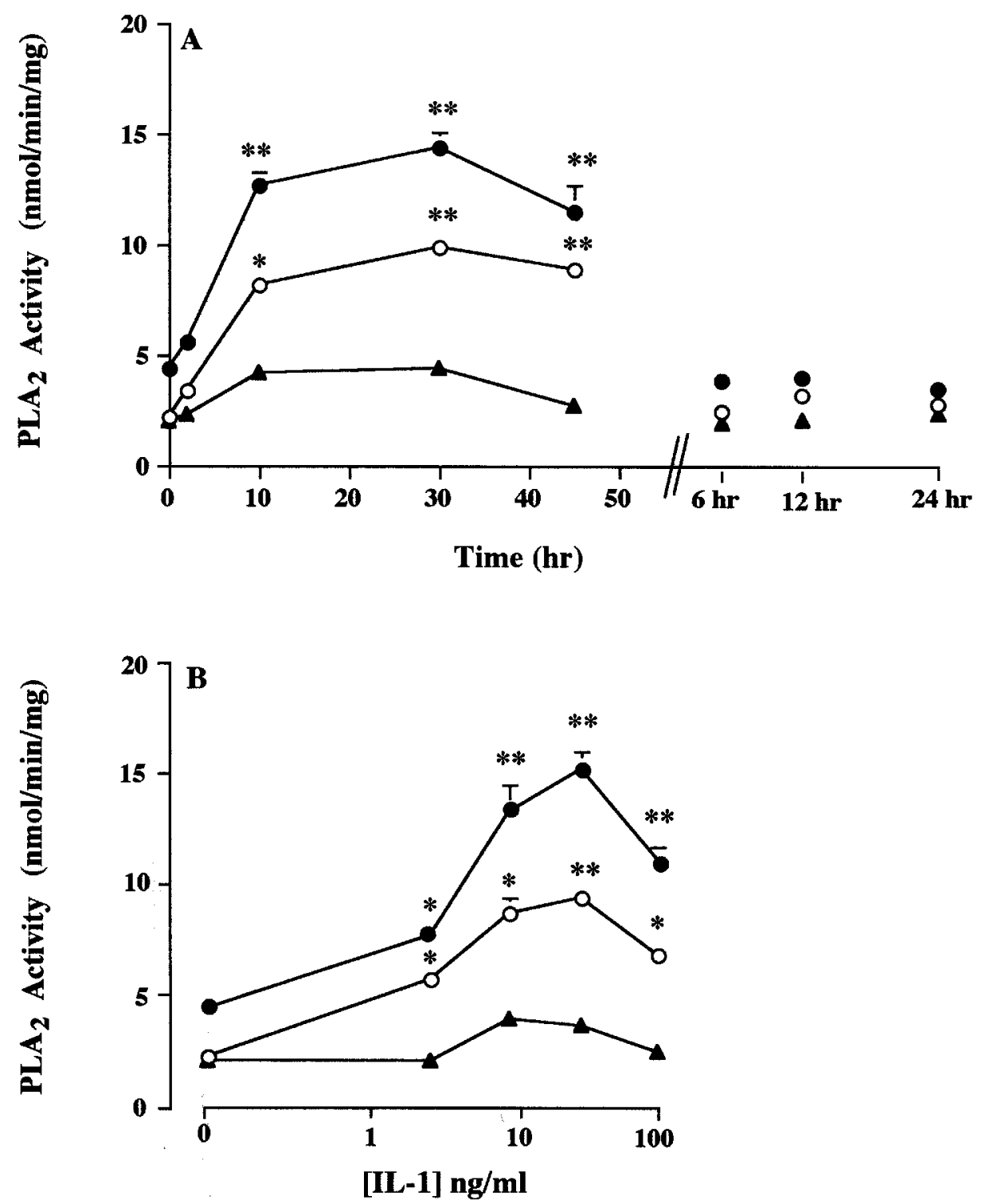

FIG. 5. Activity of total $(\bullet)$, secretory $(\bigcirc)$, and cytoplasmic PLA $(\mathbf{\Delta})$ : (A) in cells treated with IL-1 $(10 \mathrm{ng} / \mathrm{ml})$ for different time periods, and $(B)$ in cells treated with different concentrations of IL- 1 for $10 \mathrm{~min}$. ${ }^{*} P<0.05, * * P<0.005 ; P$ value represents the comparison of the effect of IL-1 on PLA $\mathrm{P}_{2}$ levels as compared with untreated control. Data are means \pm SE for six separate experiments.

activity were increased signific antly with IL-1 $\beta$ treatment and reached a peak of activity of around $10 \mathrm{nmol} / \mathrm{min} / \mathrm{mg}$ protein $30 \mathrm{~min}$ after IL-1 $\beta$ addition at a concentration of $30 \mathrm{ng} / \mathrm{ml}$ (Fig. 5). This increase correlated well with the increase observed in IL1 -induced PLAP levels. sPLA 2 levels went back to baseline levels and stayed at control levels $24 \mathrm{~h}$ after IL-1 $\beta$ treatment. The activity of $\mathrm{CPLA}_{2}$ did not change by IL-1 treatment over the time course or the concentration range studied, as shown in Fig. 5.

\section{Levels of COX-1 and COX-2 in epithelial cells}

To test whether IL-1 had any effect on the COX pathway, COX-1 and COX-2 protein levels were measured at different IL-1 $\beta$ concentrations and different times. IL-1 had no effect on COX-1 protein levels (data not shown). However, COX-2, which was not present in the intestinal epithelial cells under control conditions (Fig. 6), was signific antly induced by IL-1 $\beta$ treatment. It reached peak levels $6 \mathrm{~h}$ post-treatment and was back to almost undetectable levels in around $24 \mathrm{~h}$.

\section{Production of $\mathrm{PGE}_{2}$ by epithelial cells and regulation by IL-1 $\beta$}

Treatment of epithelial cells for long times with IL-1 $\beta$ causes a biphasic increase in the levels of $\mathrm{PGE}_{2}$ (Fig. 7). The first peak that was observed $30 \mathrm{~min}$ after addition of IL- $1 \beta$ correlated well $w$ ith the increase in PLAP levels as already seen and published earlier. ${ }^{7,8}$ The second peak appeared $6 \mathrm{~h}$ after the addition of IL$1 \beta$, correlating well with the increase observed in 

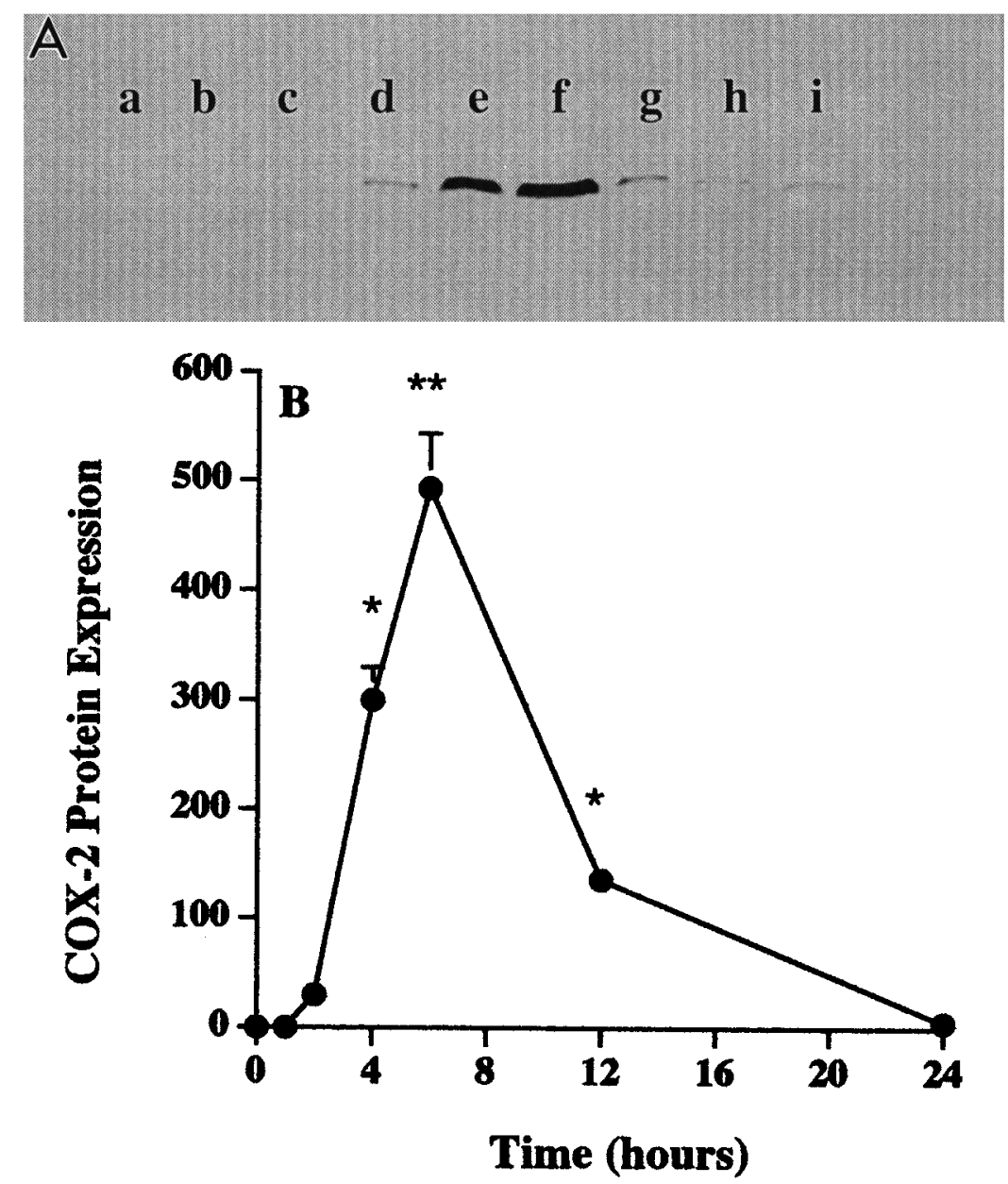

FIG. 6. (A) A representative Western blot (one of three experiments) showing induction of COX-2 (size, $70 \mathrm{kD}$ ) protein synthesis by IL-1 $\beta$ for different time periods as follows: lane a, $0 \mathrm{~min}$; lane b, $30 \mathrm{~min}$; lane c, $1 \mathrm{~h}$; lane d, $2 \mathrm{~h}$; lane e, $4 \mathrm{~h}$; lane f, $6 \mathrm{~h}$; lane g, $8 \mathrm{~h}$; lane h, $12 \mathrm{~h}$; and lane i, $24 \mathrm{~h}$. (B) Levels of COX-2 in cells treated with IL-1 $\beta(10 \mathrm{ng} / \mathrm{ml})$ for $24 \mathrm{~h}$. ${ }^{*} P<0.05,{ }^{*} P<0.005 ; P$ value represents the comparison of the effect of IL-1 $\beta$ on COX-2 levels as compared with untreated control. Data are means \pm SE for three separate experiments.

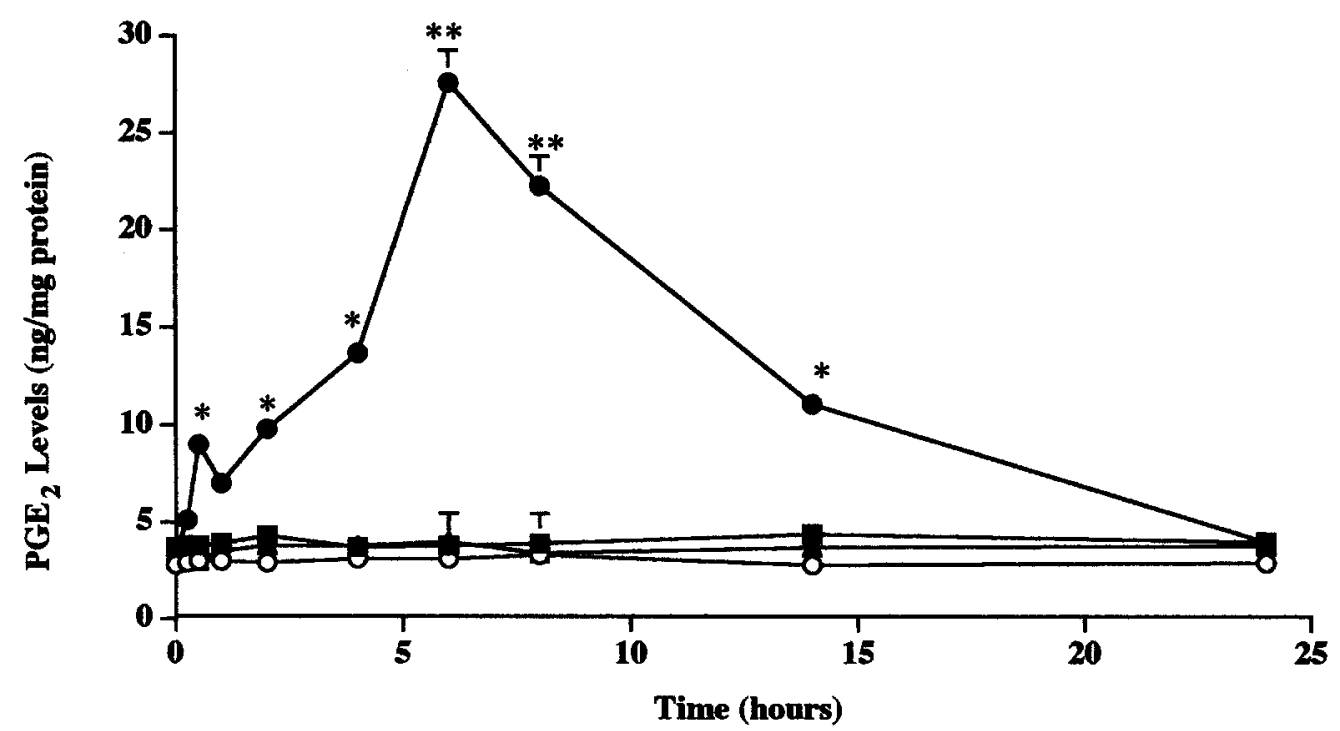

FIG. 7. Levels of $\mathrm{PGE}_{2}$ in $(\bullet)$ cells treated with IL-1 $(10 \mathrm{ng} / \mathrm{ml})$ as compared with $(\square)$ control untreated cells, with $(\bigcirc)$ cells treated with the IL- 1 ra and with $(\boldsymbol{\Delta})$ cells treated with IL-1 $\beta$ and IL-1ra together. ${ }^{*} P<0.05$, ** $P<0.005 ; P$ value represents the comparison of the treatment on $\mathrm{PGE}_{2}$ production as compared with untreated time control. Data are means $\pm \mathrm{SE}$ for six separate experiments. 


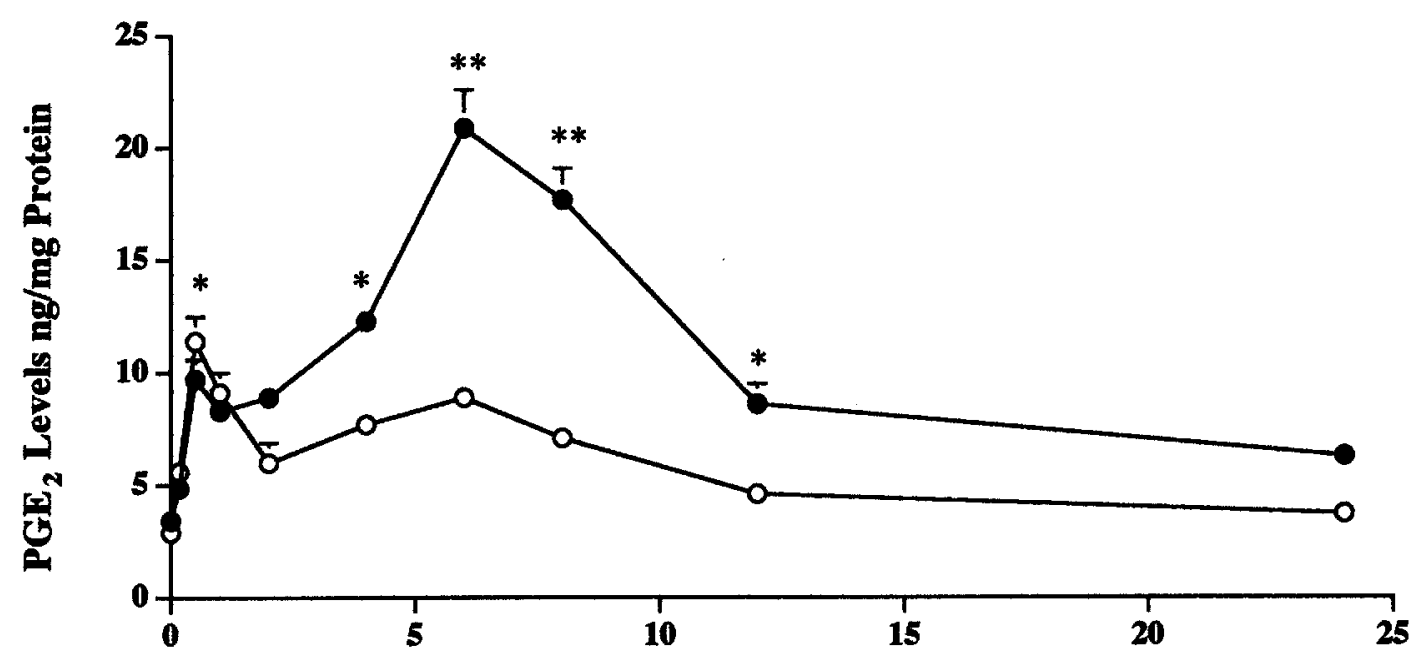

Time (hours)

FIG. 8. Levels of $P G E_{2}$ in $(\Theta)$ cells treated with IL-1 $\beta(10 \mathrm{ng} / \mathrm{ml})$ as compared with $(\bigcirc)$ cells treated with the IL-1 $1 \beta$ and COX-2 synthesis inhibitor L-745,337. ${ }^{*} P<0.05 ; P$ value represents the comparison of the effect of IL-1 $\beta$ on PGE 2 production as compared with COX-2 inhibitor treated cells. Data are means \pm SE for four separate experiments.

COX-2 levels already reported. Both peaks were completely abolished when cells were pretreated with IL-1 receptor antagonist (IL-1 ra) $(100 \mathrm{ng} / \mathrm{ml})$, providing further evidence that these colonic cells possess a functional IL-1 receptor. Only the second peak was abolished when the cells were pretreated with a selective COX-2 inhibitor L-745,337 (5-methanesulfonamide-6-(2,4-difluoro th io phenyl)-1-indanone, a generous gift from Merck-Frosst Center for Therapeutic Research, Canada ${ }^{12}$ ) before the addition of IL1 , as show $\mathrm{n}$ in Fig. 8, providing additional evidence that the second peak in $\mathrm{PGE}_{2}$ production is indeed due to COX-2 induction.

\section{Discussion}

Cytokines play a vital role in coordinating inflammatory responses. They are involved in responses to viral and bacterial infections, immunity and hemopoiesis. Various interleukins and other cytokines have been found to be widespread in their distribution and to exert different effects among different cell populations. This complex network of regulatory factors may be especially important in the mucosa of the gastrointestinal tract. Intestinal epithelial cells express and respond to several active cytokines, including IL-1, IL2 , IL- 6 , TNF- $\alpha$, IFN- $\gamma$ and TGF- $\beta .{ }^{13-17}$ The gastrointestinal mucosal immune response system has been recognized to encompass a diverse mixture of cells within the mucosal lamina propria and gut associated lymphoid tissue, whose functional properties are both mediated and modulated by a highly complex range of cytokines.

IL-1 has been shown to be a major constituent in mucosal inflammation. Incubation of rabbit colon with IL-1 $\beta$ induces mucosal production of $\mathrm{PGE}_{2}$, $\mathrm{PGF}_{1 \alpha}$ and thromboxane. ${ }^{4}$ Cominelli et al. ${ }^{18}$ found elevated IL-1 levels in the colon of rabbits with immune-complex-induced colitis. The levels of IL-1 correlated $w$ ith the degree of inflammation. IL-1 also regulates the rate of proliferation in keratinocytes, ${ }^{19}$ thymic epithelium ${ }^{20}$ and fibroblasts, ${ }^{21,22}$ and affects intestinal epithelial cell proliferation. These studies suggest that IL-1 receptors are present on intestinal epithelial cells and that IL-1 might act directly on the intestinal epithelium. IL-1 R have been shown to be present on IEC-1 8 rat intestinal epithelial cells ${ }^{23}$ and on a human colon cancer cell line ${ }^{24}$ which resembles the type I IL-1 receptor. Similar findings were found in the present study, where the IL-1 receptor, type I, was identified on the colonic epithelial cell membranes. Thus, the biological effects observed in the colonic epithelial cells in inflammation are due to the IL-1 receptor type I, as has been suggested in other cell types. ${ }^{25}$

Although it is true that in the inflamed intestine the chief secretors of eicosanoids are likely to be infiltrating monocytes and/or macrophages and neutrophils, the question remains whether there is local prostanoid production by epithelial cells and whether that production is regulated by agonists in the cell milieu. We have shown that IL-1 $\beta$ induces the synthesis of PLAP in the rabbit distal colonic mucosa that in turn activates $\mathrm{PLA}_{2}$ to result in increased levels of $\mathrm{PGE}_{2} \cdot{ }^{6,8}$ In the present study, we were able to show that rabbit colonic epithelial cells also express functional COX and $\mathrm{PLA}_{2}$ enzyme, and are able to produce measurable basal amounts of $\mathrm{PGE}_{2}$. $\mathrm{PGE}_{2}$ levels were significantly increased $w$ hen the cells were stimulated with IL-1 $\beta$. This increase is due to increases in the activity of the 
enzymes involved in the prostaglandin metabolism pathway, mainly $\mathrm{PLA}_{2}$ and/or COX.

Components of membrane phospholipids play an important role in cellular signal transduction. The formation of certain lipid second messengers occurs as the result of the $\mathrm{PLA}_{2}$-catalyzed cleavage of the fatty acid from phospholipids. The released fatty acids may regulate cellular functions themselves or, in the case of arachidonic acid, may be metabolized to bioactive prostaglandins and leukotrienes. These latter metabolites govern cellular functions as diverse as inflammation, ion channel activities and neurotransmission. ${ }^{26}$ The release of arachidonic acid-derived lipid mediators is a characteristic of chronic and acute inflammation. There are multiple PLA $_{2}$ isoforms $w$ ith varying structural and functional characteristics. IL-1 $\beta$ has been show $n$ to specifically increase the activity of the small molecular weight $\mathrm{PLA}_{2}$ (of group II) in EL-4 murine $\mathrm{T}$ cells without any effect on the high molecular weight enzyme. ${ }^{27}$ In our studies, we found that IL-1 $\beta$ induced an increase in sPLA $\mathrm{P}_{2}$ activity threeto fivefold without affecting the cytoplasmic form of the enzyme cPLA $A_{2}$. This enhanced enzyme activity induced by IL-1 $\beta$ is due to the increased levels of PLAP as we have shown recently, ${ }^{6,8}$ which was originally isolated by its antigenic and functional similarities to melittin, a bee venom peptide. ${ }^{28}$

COX enzyme converts arachidonic acid to prostaglandins and thromboxanes. COX exists in at least two isoforms, a constitutive isoform, COX-1, and an inducible form, COX-2. The COX isoforms are encoded by genes located on different chromosomes ${ }^{29}$ and are only $60 \%$ identical with the catalytic regions being conserved. COX-1 seems to represent most of the activity under basal conditions, while COX-2, which is normally undetectable in most tissues, appears to be the predominant isoform present under inflammatory conditions. In the present study, IL-1 $\beta$ treatment had no effect on the levels of COX-1, but induced the synthesis of COX-2 significantly. These IL- $1 \beta$-induced increases observed in PLA 2 and COX-2 would therefore result in a large amount of prostaglandin production. Interestingly, IL-1 $\beta$ caused a biphasic increase in the levels of $\mathrm{PGE}_{2}$, where the first peak was reached at $30 \mathrm{~min}$ and correlated well with the increase of PLAP levels and PLA $\mathrm{P}_{2}$ activity, and the second peak reached at $6 \mathrm{~h}$ was completely due to the increase in COX-2 levels.

In summary, cultured colonic epithelial cells isolated from normal adult rabbits and grow $n$ in culture possess the IL-1 receptor and all the machinery necessary to produce prostanoids both constitutively and in response to inflammatory stimuli. The presence of IL-1 receptor on these epithelial cells suggests that cytokines might regulate epithelial cell function directly, for example, to produce $\mathrm{PGE}_{2}$ in response to inflammatory stimuli. This is the first study describing the presence of IL-1 receptor in colonic epithelial cells and describing the mechanism of action of how IL-1 can directly regulate epithelial cell function. The biphasic increase in $\mathrm{PGE}_{2}$ levels seems to reflect the different mechanis ms by which IL-1 can affect epithelial cell function under acute or under chronic conditions, which can reflect the mechanisms involved in acute and chronic inflammation in the intestine. The acute response is due to PLAP/PLA pathway and the chronic response due to COX-2 pathway, both of which will lead to inc re ases in $\mathrm{PGE}_{2}$.

ACKNOWLEDGEMENTS: Funding was from the American University of Beirut (University Research Board), from the Diana Tamari Sabbagh Foundation and from the Lebanese National Council for Scientific Research. We thank Dr J.S. Bomalaski for the antimelittin antibodies and Dr Holtsberg for the PLAP probe, and thank Merck Frosst Center for Therapeutic Research, Quebec, Canada for the COX-2 inhibitor L-745,337.

\section{References}

1. Bomsztyk K, Sims JE, Stanton TH, Slack J, McMahan CJ, Valentine MA, Dower SK. Evidence for different interleukin 1 receptors in murine Band T-cell lines. Proc Natl Acad Sci USA 1989; 86: 8034-8038.

2. Sims JE, March CJ, Cosman D et al. cDNA expression cloning of the IL-1 receptor, a member of the immunoglobulin superfamily. Science 1988; 241: 585-589.

3. Sims JE, Acres RB, Grubin CE, McMahan CJ, Wignall JM, March CJ, Dower SK. Cloning the interleukin receptor from human T cells. Proc Natl Acad Sci USA 1989; 86: 8946-8950.

4. Cominelli F, Nast CC, Dinarello CA, Gentilini P, Zisper RD. Regulation of eicosanoid production by rabbit colon in interleukin-1. Gastroenterolgy 1989; 97: 1400-1405.

5. Mahida YR, Wu K, Jewell DP. Enhanced production of interleukin $1 \beta$ by mononuclear cells isolated from mucosa with active ulce rative colitis of Crohn's disease. Gut 1989; 30: 835-838.

6. Homaidan FR, Desai H, Zhao L, Broutman G, Burakoff R. Regulation of electrolyte transport with IL-1 $\beta$ in the rabbit distal colon. Mediators Inflammation 1995; 4: 61-66.

7. Homaidan FR, Zhao LM, Burakoff R. IL-1 induces the synthesis of phospholipase $\mathrm{A}_{2}$-activating prote in in the distal colon. Gastroenterology 1995; 108: A838.

8. Homaidan FR, Zhao LM, Burakoff R. IL-1 induces the synthesis of phospholipase $\mathrm{A}_{2}$-activating protein in the rabbit intestine. Am J Physiol 1997; 272: G1338-G1346.

9. LeDuc L, Brown L, Vidrich A. Bradykinin and FMLP stimulate prostanoid production by adult rabbit colonocytes in culture. Am J Physiol 1994; 267: G778-G785.

10. Laemmli UK. Cleavage of structural proteins during the assembly of the head of bacteriophage T4. Nature 1970; 227: 680-685

11. Young IT. Proof without prejudice: use of the Kolmogrov-Smirnov test for the analysis of histograms from flow systems and other sources. J Histochem Cytochem 1977; 25: 935-941.

12. Chan CC, Boyce S, Brideau C et al. Pharmacology of a selective cycloox ygenase-2 inhibitor, L-745,337: a novel nonsteroidal anti-inflammatory agent with an ulcerogenic sparing effect in rat and nonhuman primate stomach. J Pharmacol Exp Therapy 1995; 274: 1531-1537.

13. Chang EB, Musch MW, Mayer L. Interleukins 1 and 3 stimulate anion secretion in chicken intestine. Gastroenterolgy 1990; 98: 1518-1524.

14. Ciacci C, Mahida YR, Dignass A, Koizumi DM, Podolsky DK. Functional interleukin-2 receptors on intestinal epithelial cells. J Clin Invest 1993; 92: $527-532$

15. Madara JL, Stafford J. Interferon- $\gamma$ directly affects barrier function of cultured intestinal epithelial monolayers. J Clin Invest 1989; 83: $724-727$

16. Shirota K, LeDuy L, Yuan SY, Jothy S. Interleukin-6 and its receptor are expressed in human intestinal epithelial cells. Virchows Arch 1990; 58: 303-308.

17. Suemori S, Ciacci C, Podolsky DK. Regulation of transforming grow th factor expression in rat intestinal epithelial cell lines. J Clin Invest 1991; 87: 2216-2221.

18. Cominelli F, Nast CC, Clark BD et al. Interleukin 1 (IL-1) gene expression, synthesis, and effect of specific IL-1 receptor blockade in rabbit immune complex colitis. J Clin Invest 1990; 86: 972-980.

19. Mertz PM, Sauder DL, Davis SC, Kilian PL, Herron AJ, Eaglstein WH. IL-1 as a potent inducer of wound re-epithelization. Prog Clin Biol Res 1991; 365: 473-480.

20. Galy AH, Hadden EM, Touraine JL, Hadden JW. Effects of cytokines on human thymic epithelial cells in culture, IL-1 induces thymic epithelial cell proliferation and change in morphology. Cell Im munol 1989; 124: $13-27$. 
21. Dukovich M, Severin JM, White SJ, Yamazaki S, Mizel SB. Stimulation of fibroblast proliferation and prostaglandin production by purified recombinant murine interleukin 1. Clin Im munol Imm unopathol 1986; 38 : 381-389.

22. Elias JA, Lentz V. IL-1 and tumor necrosis factor synergistically stimulate fibroblast IL-6 production and stabilize IL-6 messenger RNA. J Im munol 1990; 145: 161-166.

23. Sutherland DB, Varilek GW, Neil GA. Identification and characte rization of the rat intestinal epithelial cell (IEC-18) interleukin-1 receptor. $\mathrm{Am} \mathrm{J}$ Physiol 1994; 266: C1198-C1203.

24. Varilek GW, Neil GA, Bishop WP. Caco-2 cells ex press type I interleukin-1 receptor: ligand binding enhances prolife ration. Am J Physiol 1994;267: G1101-G1 107

25. Sims JE, Gayle MA, Slack JL et al. Interleukin 1 signaling occurs exclusively via the type I receptor. Proc Natl Acad Sci USA 1993; 90 6155-6159.
26. PruzanskiW,Vadas P. Phos pholipase A2-a mediator between prox imal and distal effectors of inflammation. Im m unolToday1991; 12: 143-146.

27. Steiner MR, Bomalaski JS, Clark MA. Responses of purified phospholipases $A_{2}$ to phospholipase $A_{2}$ activating protein (PLAP) and melittin. Biochim Biophys Acta 1993; 1166: 124-130.

28. Clark MA, Conway TM, Shorr RGL, Crooke ST. Identification and isolation of a mammalian prote in which is antigenically and functionally related to the phospholipase $A_{2}$ stimulatory peptide melittin. J Biol Chem 1987 262: $4402-4406$.

29. Langenbach R, Morham SG, Tiano HF et al. Prostaglandin synthase 1 gene distuption in mice reduces arachidonic acid-induced inflammation and indomethac in-induced gastric ulceration. Cell 1995; 83: 483-492.

\section{Received 11 June 1999; \\ accepted 2 August 1999}




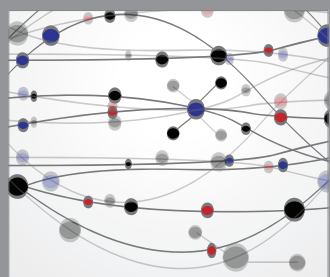

The Scientific World Journal
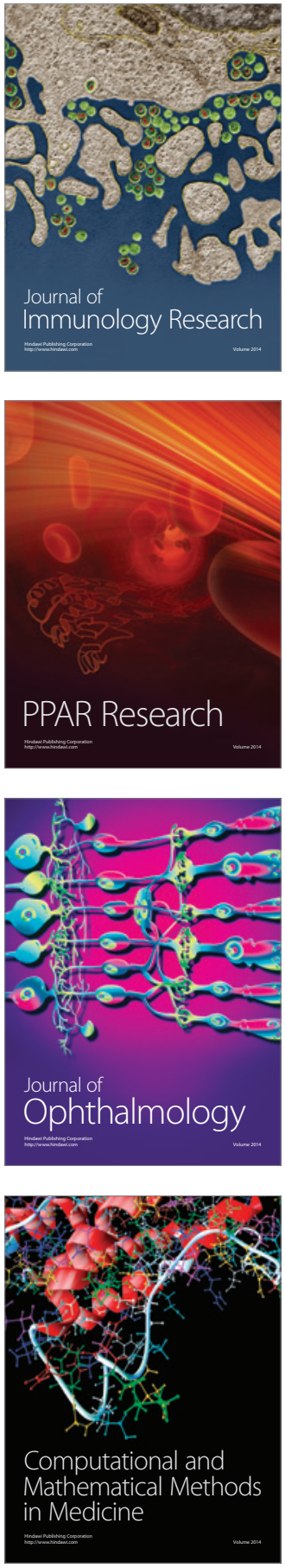

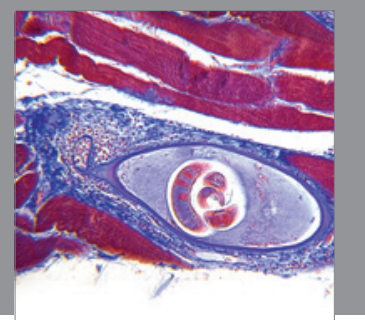

Gastroenterology

Research and Practice
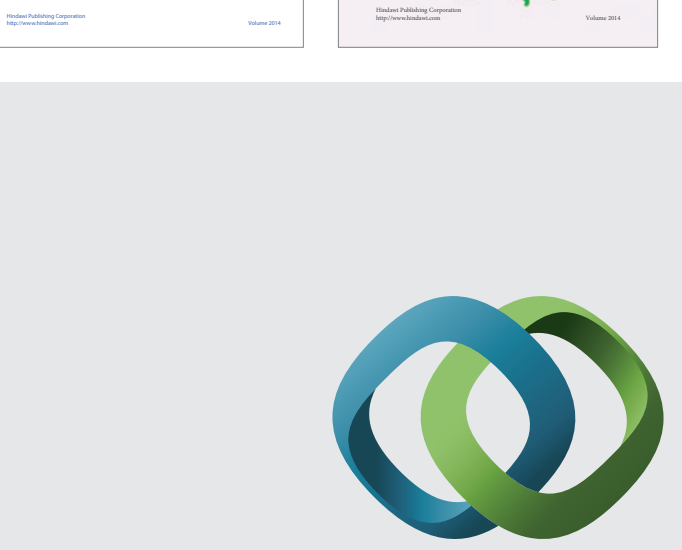

\section{Hindawi}

Submit your manuscripts at

http://www.hindawi.com
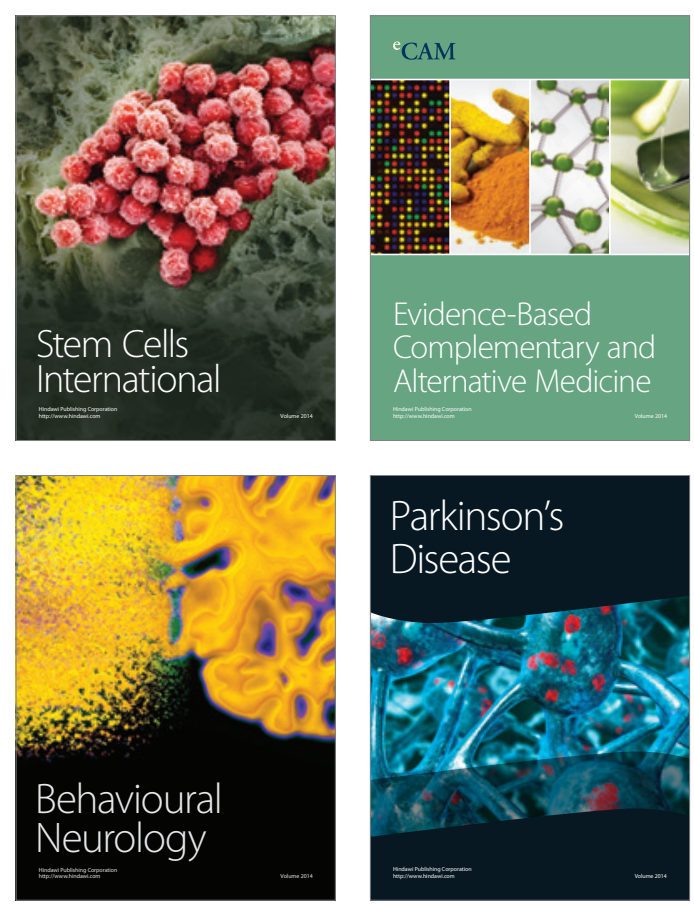

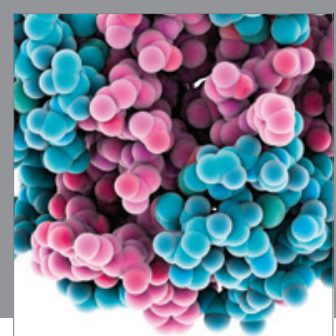

Journal of
Diabetes Research

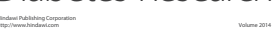

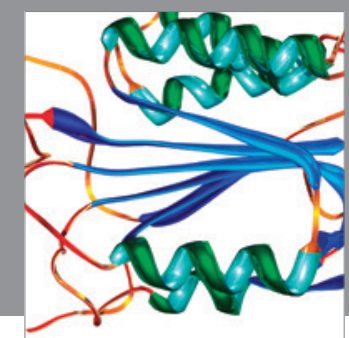

Disease Markers
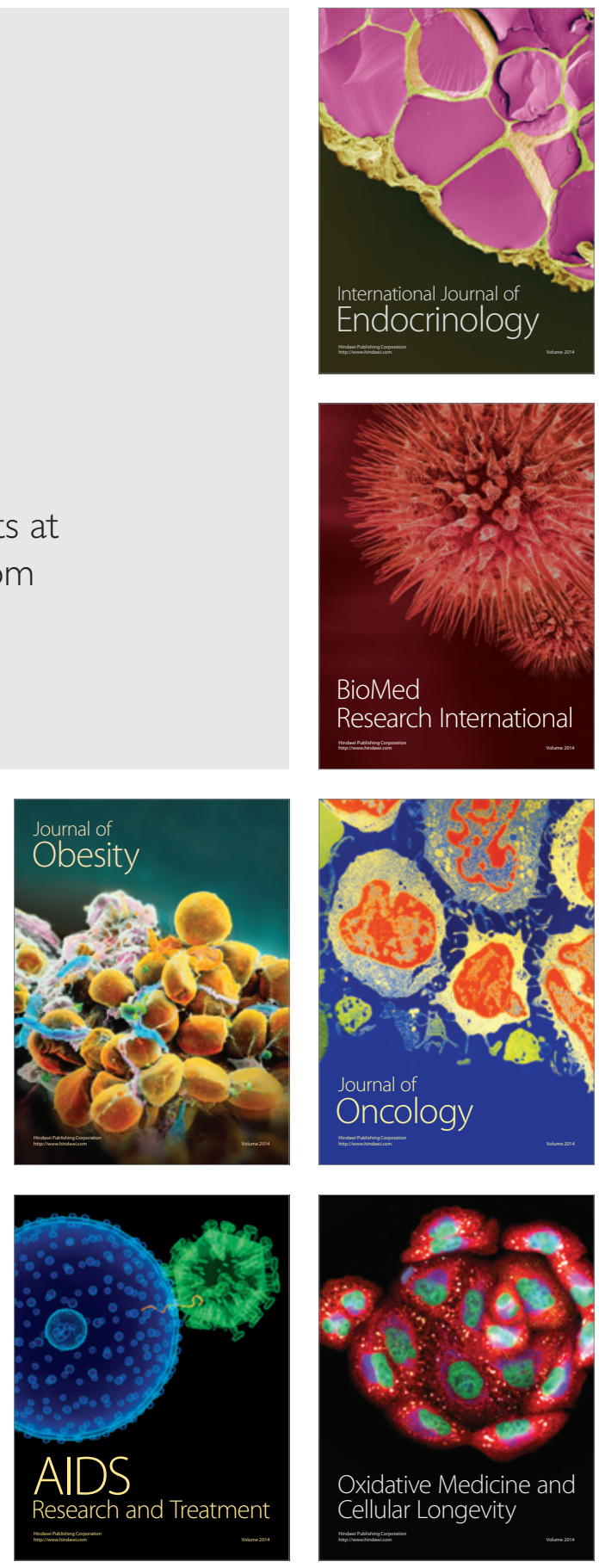